\title{
Seeing the Elephant: A Systematic Scoping Review and Comparison of Patient-Centeredness Conceptualizations from Three Seminal Perspectives [Corrigendum]
}

\begin{abstract}
Olson AW, Stratton TP, Isetts BJ, Vaidyanathan R, Van Hooser JC, Schommer JC. J Multidiscip Healthc. 2021;14:973-986.
\end{abstract}

The authors have advised that there are errors in Table 2 on page 981 .

The text "Clinical \& Patient-reported" and "Patientreported only" for the Nursing and Health Policy columns in the 5. Outcomes of Interest row should read "Patient- reported only" and "Clinical \& Patient-reported", respectively.

The text "“"Patient"-Centered" and "“"Person"-Centered" for the Nursing and Health Policy columns in the 6 . Language row should read "“Person"-Centered" and ““'Patient”-Centered", respectively.

The authors apologize for these errors and advise it does not affect the conclusions of the paper.

\section{Publish your work in this journal}

The Journal of Multidisciplinary Healthcare is an international, peerreviewed open-access journal that aims to represent and publish research in healthcare areas delivered by practitioners of different disciplines. This includes studies and reviews conducted by multidisciplinary teams as well as research which evaluates the results or conduct of such teams or healthcare processes in general. The journal covers a very wide range of areas and welcomes submissions from practitioners at all levels, from all over the world. The manuscript management system is completely online and includes a very quick and fair peer-review system. Visit http://www.dovepress.com/testimonials. php to read real quotes from published authors. 